\title{
Analisis dan Perancangan Sistem Informasi Penerbitan Surat di PDAM Tirta Moedal Kota Semarang Cabang Timur
}

Analysis and Design of Publishing Letter Information System in PDAM Tirta Moedal Semarang Timur

\author{
Roni Kurniawan', Jeffry Nur Rifa' ${ }^{2}{ }^{2}$, Much Aziz Muslim ${ }^{3}$ \\ 1,2,3 Jurusan Ilmu Komputer, FMIPA, Universitas Negeri Semarang \\ Jalan Taman Siswa, Sekaran, GunungPati, Semarang, 50229 \\ e-mail: *11kroni477@gmail.com, ${ }^{2}$ jeffry.rifai@gmail.com, ${ }^{3}$ a212muslim@yahoo.com
}

\begin{abstract}
Abstrak
Penerbitan surat berita acara merupakan aspek penting dalam kegiatan perusahaan/lembaga karena merupakan hal pertama yang dikerjakan sebelum melakukan kegiatan lainnya. Salah satunya di PDAM Tirta Moedal Kota Semarang Cabang Timur yang menerbitkan surat berita acara terkait pemasangan. Sebelumnya PDAM Tirta Moedal masih menggunakan aplikasi Microsoft Excel. Sedangkan teknologi aplikasi berbasis web pada proses bisnis atau presentasi mengalami perubahan yang signifikan. Sehingga semakin diminatinya sistem informasi berbasis web yang menjadi salah satu faktor untuk peneliti menggunakan web sebagai penerapan penerbitan surat berita acara pemasangan di PDAM Tirta Moedal. Perancangan sistem informasi penerbitan surat berita acara pemasangan dapat diimplementasikan dengan baik menggunakan bahasa pemograman PHP dan menggunakan database MySql. Dalam pembuatan perancangan sistem informasi ini melalui tahapan SDLC dari tahap Planning, Analysis, Design, Implementation, dan Maintainance. Pada penelitian ini sistem dapat menerbitkan dua surat yakni Surat Berita Acara Pemasangan Sambungan dan Surat Berita Acara Pemasangan Meter Air. Hasil analisis kelayakan yang dilakukan dengan skala likert dan garis kontinum diperoleh nilai kelayakan sistem sebesar 4.28 dengan kategori Sangat Layak untuk diterapkan.
\end{abstract}

Kata kunci-Sistem Informasi, Penerbitan Surat, SDLC, PHP

\begin{abstract}
The issuance of newsletter is an important aspect in the activities of the company / institution because it is the first thing to do before doing other activities. One of them is in PDAM Tirta Moedal Kota Semarang Eastern Branch which publishes newsletter realted installation. Previously PDAM Tirta Moedal used Microsoft Excel application. While web-based application technology on business processes or presentations undergo significant changes. So, the webbased information system became one of the factors for researchers to use the web as the implementation of the issuance of installation newsletter in PDAM Tirta Moedal. The design of information systems publishing newsletter of installation can be implemented well using PHP programming language and using MySql database. In developing this information system through the stages of SDLC from Planning, Analysis, Design, Implementation, and Maintainance. In this study the system can publish two letters namely Connection Newsletter and newsletter of Water Meter Installation. Result of feasibility analysis conducted by using likert scale and continuum line obtained the feasible value 4.28 with category "Very Eligible" to apply.
\end{abstract}

Keywords—Information System, newsletter, SDLC, PHP 


\section{PENDAHULUAN}

Penerbitan surat berita acara merupakan aspek penting dalam kegiatan perusahaan/lembaga karena merupakan hal pertama yang dikerjakan sebelum melakukan kegiatan lainnya [1]. Salah satunya di PDAM Tirta Moedal Kota Semarang Cabang Timur yang menerbitkan surat berita acara pemasangan. Surat berita acara pemasangan harus direkam ke dalam sistem dengan manajemen yang benar agar jika suatu saat dibutuhan dapat dicari dan digunakan dengan akses yang mudah dan cepat. Surat berita pemasangan adalah surat yang dikeluarkan oleh PDAM Tirta Moedal sebagai surat perintah dilakukannya proses perbaikan atau penyambungan baru dari jaringan pipa kepada masyarakat. Surat ini akan dibawa oleh petugas lapangan yang nantinya akan dikembalikan lagi ke kantor untuk direkap kembali setelah selesai dari proses penyambungan oleh pihak lapangan.

Sebelumnya PDAM Tirta Moedal masih menggunakan aplikasi Microsoft Excel. Microsoft Excel memang efektif untuk mengolah data yang simple tetapi tidak bisa menyimpan data yang semakin banyak atau bertambah tiap hari. Microsoft Excel tidak efisien jika digunakan untuk menyimpan data parsial terutama dalam hal kapasitas penyimpanan yang dihasilkan. Microsoft Excel juga tidak memiliki validasi terkait data data yag ada di cell sehingga redudansi data bisa saja terjadi jika menggunakan aplikasi ini.

Peran Microsoft Excel yang masih belum sempurna tersebut dapat digantikan dengan Mysql, dimana mysql dapat mengatasi kekurangan tersebut dengan mudah. MySQL adalah sebuah perangkat lunak system manajemen basis data SQL (DBMS) yang multithread, dan multiuser. MySQL adalah implementasi dari system manajemen basisdata relasional (RDBMS) [2].

Teknologi informasi pada saat ini merupakan salah satu kebutuhan yang sangat penting dalam kehidupan sehari-hari karena dapat mempermudah manusia dalam membantu mengerjakan pekerjaannya [3]. Teknologi aplikasi berbasis web pada proses bisnis atau presentasi mengalami perubahan yang signifikan [4]. Sehingga semakin diminatinya sistem informasi berbasis web yang menjadi salah satu faktor untuk peneliti menggunakan web sebagai penerapan penerbitan surat berita acara pemasangan di PDAM Tirta Moedal. Pembuatan sistem menggunakan bahasa pemprogaman PHP dimana PHP (akronim dari PHP: Hypertext Preprocessor) adalah bahasa pemrograman yang berfungsi untuk membuat website dinamis maupun aplikasi web [5]. PHP dapat berinteraksi dengan database, file dan folder tidak seperti html biasa yang hanya menampilkan konsten secara statis. PHP dengan mudah bisa melakukan koneksi dengan database (MySql) sehingga proses rekam data dan proses menampilkan data akan menjadi dinamis dan tidak terjadi redundansi data.

Penelitian yang dilakukan Usman [1], melakukan merancang sistem informasi untuk mendukung kebutuhan informasi pengolahan data surat persetujuan berlayar di kantor unit penyelenggara pelabuhan kelas III Kuala Gaung. Sehingga memungkinkan peneraan sistem informasi untuk memudahkan dalam pembuatan surat. Penelitian yang dilakukan oleh Sugiharti, merancang sistem aplikasi surat masuk dan keluar dengan menggunakan Visual Basic 6.0, MySQL sebagai databasenya dan crystal report untuk pembuatan laporannya. Data yang digunakan adalah data surat di PT. Angkasa Pura 1 (Persero) kantor cabang Bandar Udara Internasional Ahmad Yani Semarang tahun 2013-2014 [6]. Muslim dalam penelitiannya merancang sistem informasi jurusan berbasis web untuk meningkatkan pelayanan dan akses informasi. Bahasa pemograman yang gunakan ialah PHP, HTML, dan MySq1 [7].

Bedasarkan uraian di atas, maka permasalahan di PDAM Tirta Moedal Kota Semarang Cabang Timur perlu dilakukan perancangan sistem informasi penerbitan surat berita acara berbasis web. Bahasa pemograman yang gunakan ialah PHP, HTML, dan MySql. Tujuan dari penelitian ini ialah menghasilkan sistem informasi penerbitan surat yang aplikatif. 


\section{METODE PENELITIAN}

Pada perancangan sistem informasi ini menggunakan beberapa tahapan yang diadopsi sesuai dengan systems development life cycle (SDLC)/siklus hidup sistem. SDLC merupakan tahapan aktivitas yang harus dikerjakan oleh pengembang sistem untuk menghasilkan sebuah sistem yang dapat dioperasikan pada organisasi pemakai sistem [8]. Adapun tahapanya disajikan pada Gambar 1. berikut.

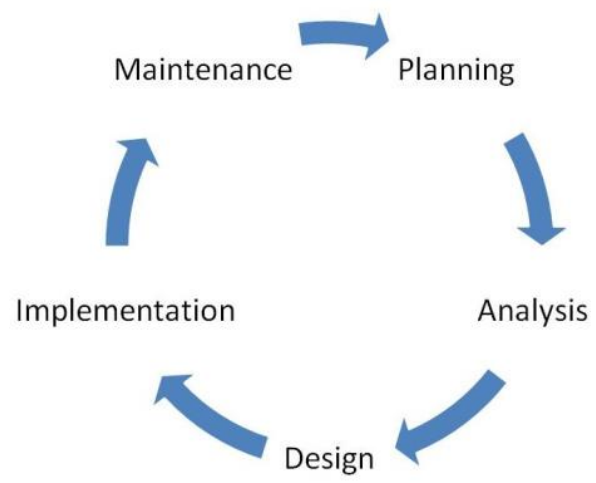

Gambar 1. Tahapan SDLC

Tahap pertama adalah Planning. Tahapan ini merupakan tahap perencanaan terkait kebutuhan dengan mengidentifikasi semua kebutuhan dari sistem yang akan dibuat. Kebutuhan dalam perencanaan ini dibagi menjadi dua yakni Kebutuhan Software dan Kebutuhan Hardware. Kebutuhan Software, memerlukan aplikasi seperti XAMPP, Teks editor, dan Browser. Sedangkan kebutuhan Hardware antara lain ialah personal komputer.

Tahap kedua adalah Analysis. Tahapan analisis fungsional dari sistem itu sendiri. Sistem Informasi penerbitan surat ini memiliki fungsional terdiri dari (1) menginputkan data sambungan baru, (2) mencetak surat berita acara pemasangan sambungan baru, (3) menginputkan data, dan (4) mencetak surat berita acara pemasangan meter air. Selain itu menganalisis hubungan basis data yang disajikan dalam ERD. ERD merupakan suatu model yang digunakan untuk menjelaskan hubungan antar data dalam basis data berdasarkan objek-objek dasar data yang mempunyai hubungan antar relasi. ERD dari Sistem Informasi Penerbitan Surat di PDAM Tirta Moedal Kota Semarang Cabang Timur disajikan pada Gambar 2. berikut.

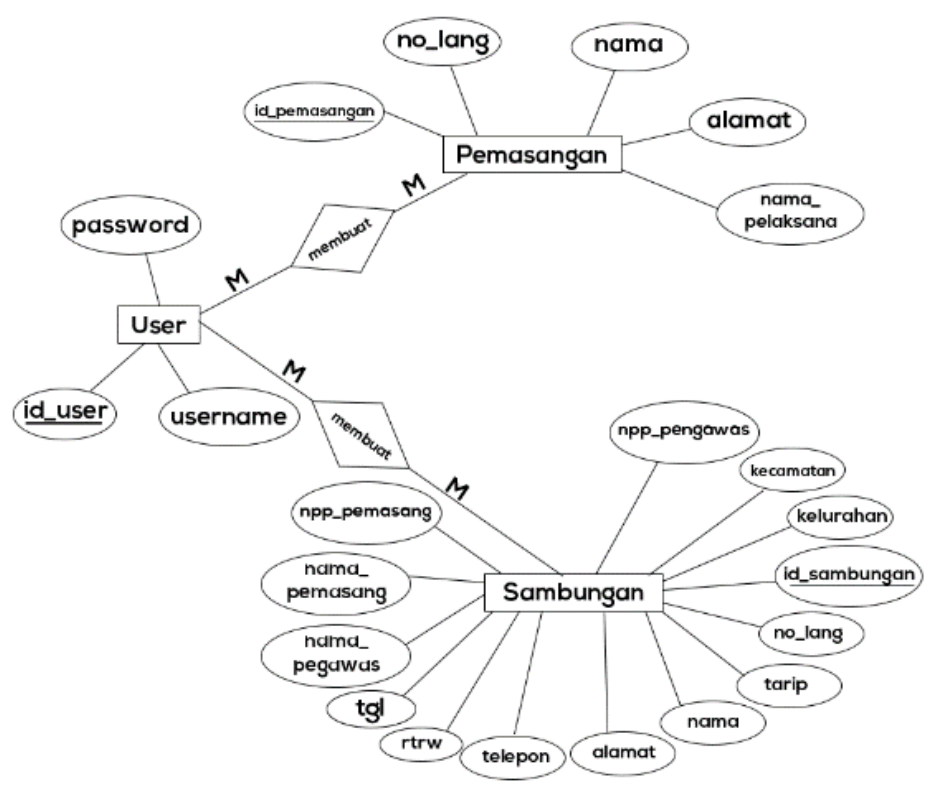

Gambar 2. ERD Sistem Informasi Penerbitan Surat 
Selain ERD, dalam analisis juga perlu membuat DFD. Data Flow Diagram (DFD) merupakan suatu model logika data atauproses yang dibuat untuk menggambarkan darimana asal data dan kemanatujuan data yang keluar dari sistem, dimana data disimpan, proses apayang menghasilkan data tersebut dan interaksi antara data yang tersimpan dan proses yang dikenalkan pada data tersebut [9]. DFD Sistem Informasi Penerbitan Surat ditujukan pada Gambar 3. berikut.

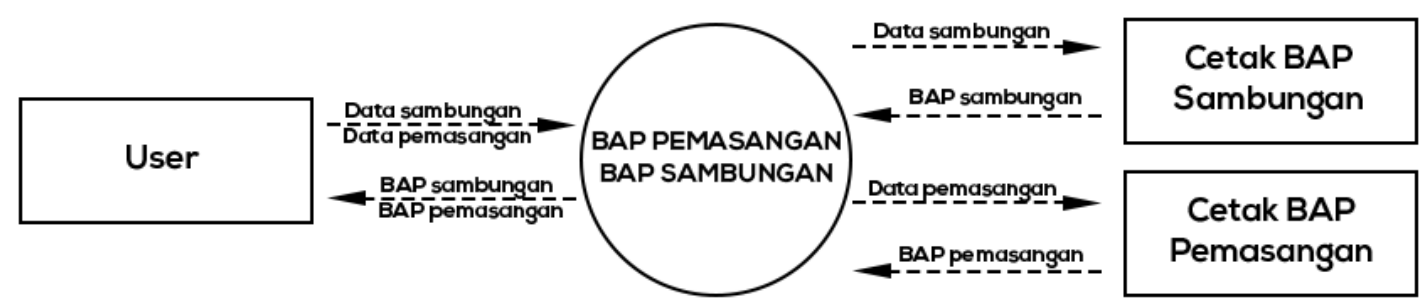

Gambar 3. DFD Sistem Informasi Penerbitan Surat

Tahap selanjutnya ialah Design. Tahapan ini melakukan desain/mock up dari sistem yang akan dibuat. Berikut adalah tampilan mock up Sistem Informasi Penerbitan Surat ditujukan pada Gambar 4. sampai Gambar 7.

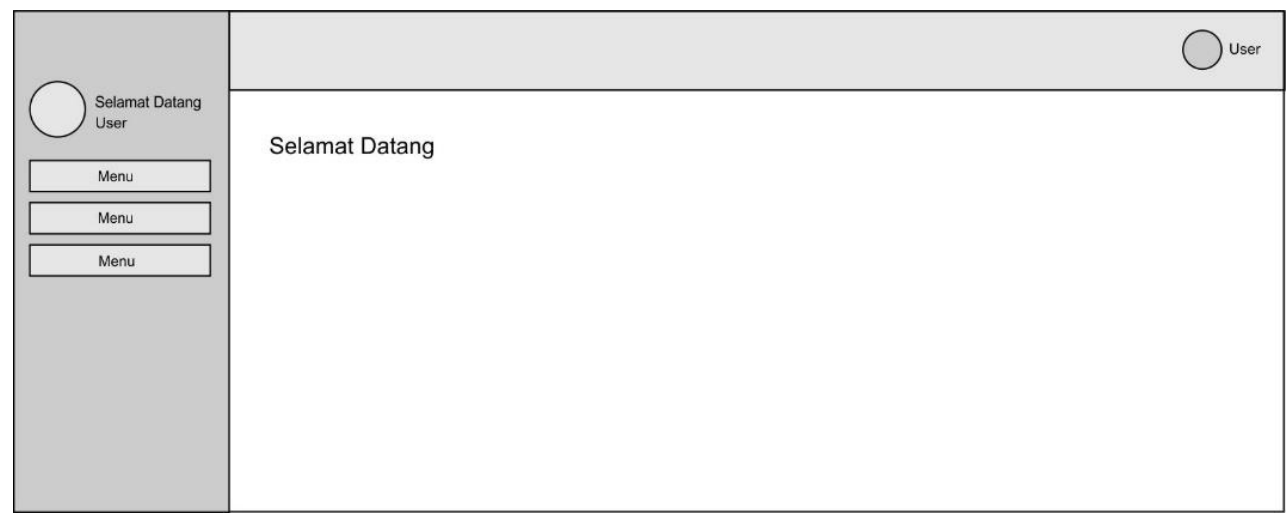

Gambar 4. Desain Tampilan Selamat Datang

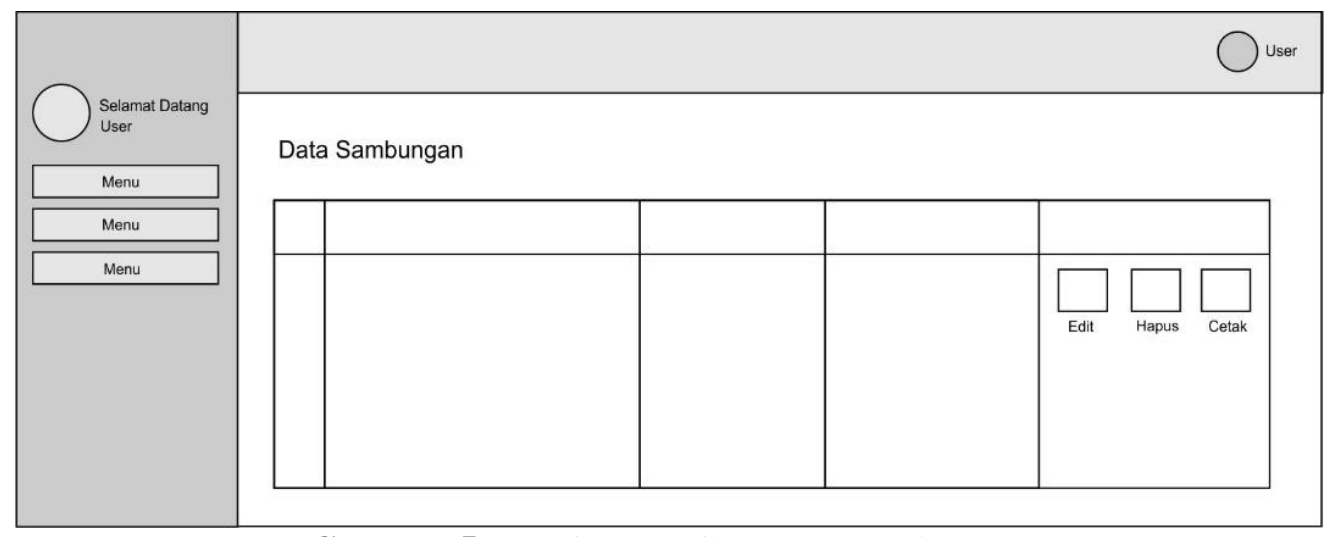

Gambar 5. Desain Tampilan Data Sambungan 


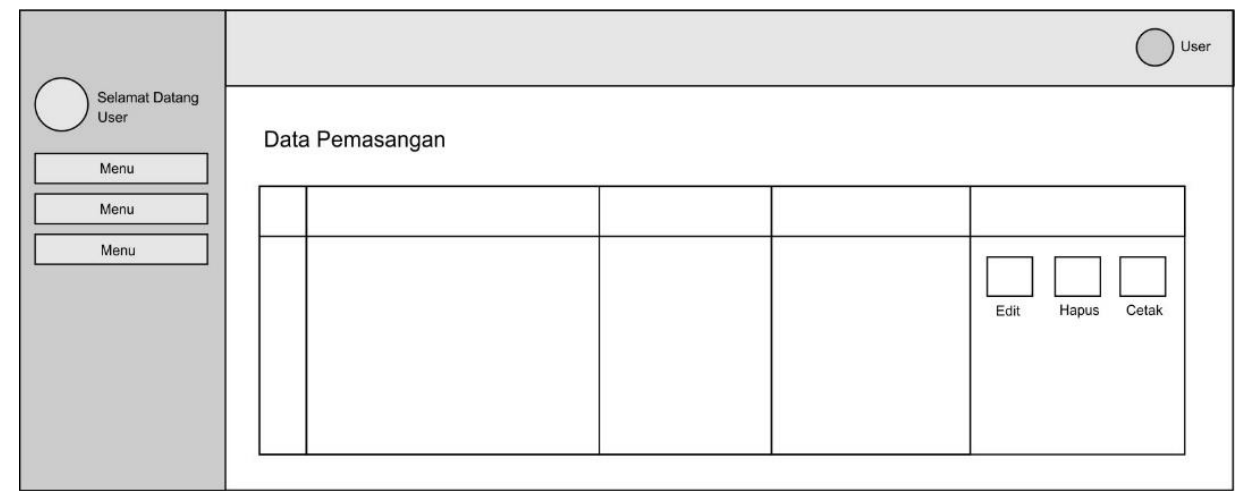

Gambar 6. Desain Tampilan Data Pemasangan

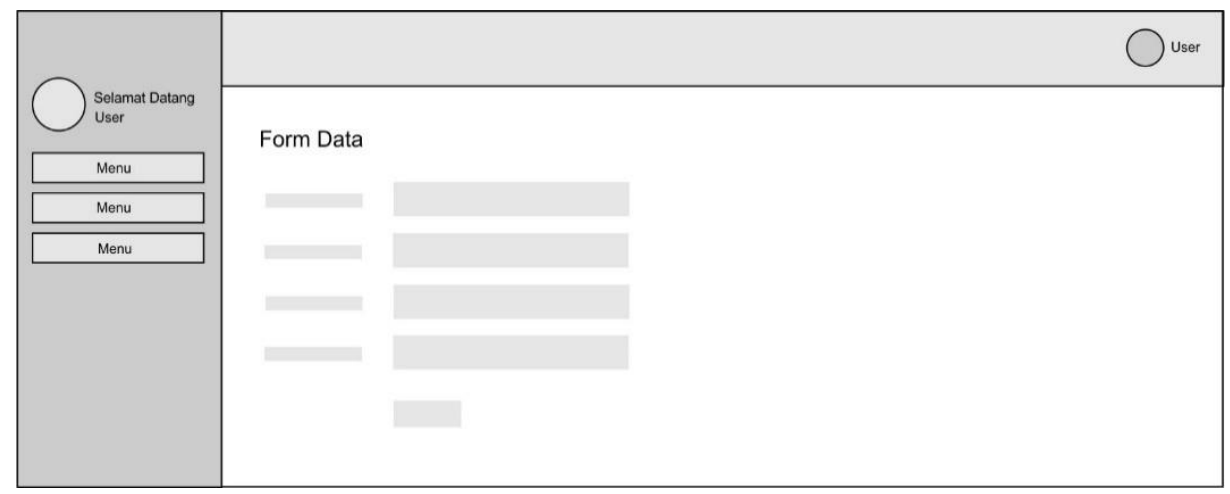

Gambar 7. Desain Tampilan Form Input Data

Tahapan selanjutnya ialah Implementation. Tahapan ini sama dengan tahap pembuatan program, yaitu melakukan pemprograman berdasarkan design dan kebutuhan yang telah dianalisis sebelumnya. Selain itu, pada tahap ini juga terdiri dari proses pengujian sistem yakni mengecek keberhasilan dari sistem. Dalam tahap ini dilakukan pengujian sebagai berikut. (1) Kesalahan bahasa yaitu kesalahan dalam penulisan kode program yang kurang tepat dengan bahasa pemrograman dari program yang digunakan; (2) Kesalahan Proses, merupakan kesalahan yang muncul ketika program dijalankan. Kesalahan ini mengakibatkan program berhenti melakukan proses sebelum seharusnya program tersebut berhenti karena program tidak menemukan objek yang dijalankan; dan (3) Kesalahan Logika, merupakan kesalahan yang cukup sulit ditemukan karena kesalahan ini tidak tampak jelas saat program dijalankan. Program tetap bisa berjalan dengan normal dan menampilkan hasil, akan tetapi hasil yang ditampilkan tidak sesuai dengan yang diharapkan [10].

Tahap terakhir ialah tahap Maintenance. Tahap ini dilaksanakan setelah sistem selesai, dengan memberikan proses pemeliharaan. Pemeliharaan ini diperlukan untuk meningkatkan efisiensi dan efektivitas kinerja sistem yang agar dalam penggunaannya dapat optimal. Selain itu, mempersiapkan apabila terjadi kesalahan saat penggunaan dan serangan malware/virus.

Setelah dilakukan pengembangan sistem, sistem informasi akan dilakukan analisis terkait kelayakannya. Analisis dilakukan dengan pemberian nilai terkait 7 aspek. Aspek-aspek tersebut antara lain, (1) User Interface, (2) Sistem Database, (3) Otentifikasi, (4) Navigasi, (5) Pengelolaan Data Surat, (6) Tujuan Sistem, dan (7) Usability. Aspek tersebut dijabarkan dalam tujuh pernyataan yang akan dinilai oleh dua ahli web. Kemudian hasil penilaian akan dihitung dengan menggunakan skala likert dan garis kontinum dari kategori Tidak Layak hingga Sangat Layak. 


\section{HASIL DAN PEMBAHASAN}

Sistem Informasi penerbitan surat berita acara pemasangan digunakan untuk mempermudah dalam melakukan pengelolaan penerbitan surat dari berita acara pemasangan. Sistem informasi ini memungkinkan pengguna untuk dapat input dari data sambungan seperti no langganan, tarip, nama, alamat dan segala sesuatu tentang pencatatan pelanggan tersebut, melakukan penyimpanan data dan mencetak surat erita acara pemasangan. Sistem informasi berita acara pemasangan ini memiliki beberapa menu diantaranya yaitu input data sambungan, data pemasangan. Dari masing masing menu dapat melakukan penambahan dari data pemasangan, melakukan edit data, hapus data dan tentunya melakukan cetak surat penerbitan itu sendiri. Untuk dapat masuk ke dalam sistem ini diperlukan register terlebih dahulu dan kemudian melakukan login kedalam sistem. Halaman awal dari sistem penerbitan surat berita acara pemsangan ini merupakan halaman login. Jadi user harus menginputkan username dan password untuk dapat masuk kedalam sistem tersebut. Berikut adalah tampilan login sistem ditujukan pada Gambar 8.

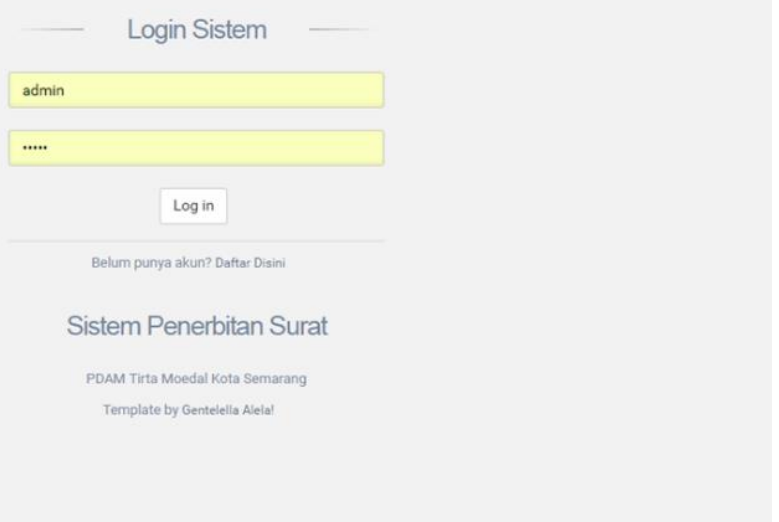

Gambar 8. Tampilan Login Sistem

Halaman selanjutnya ialah halaman terkait pengelolaan. Halaman ini merupakan halaman yang dapat diakses user setelah melakukan login. Pada halaman ini terdapat 2 menu utama yatu Data Sambungan dan Data Pemasangan. Berikut tampilannya ditujukan pada Gambar 9.

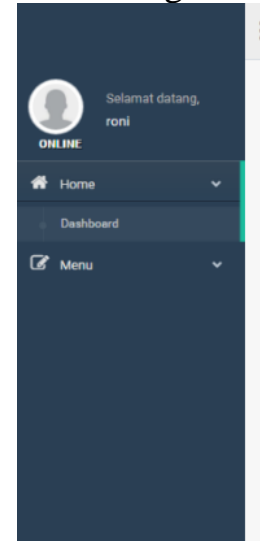

Gambar 9. Tampilan Menu Awal 

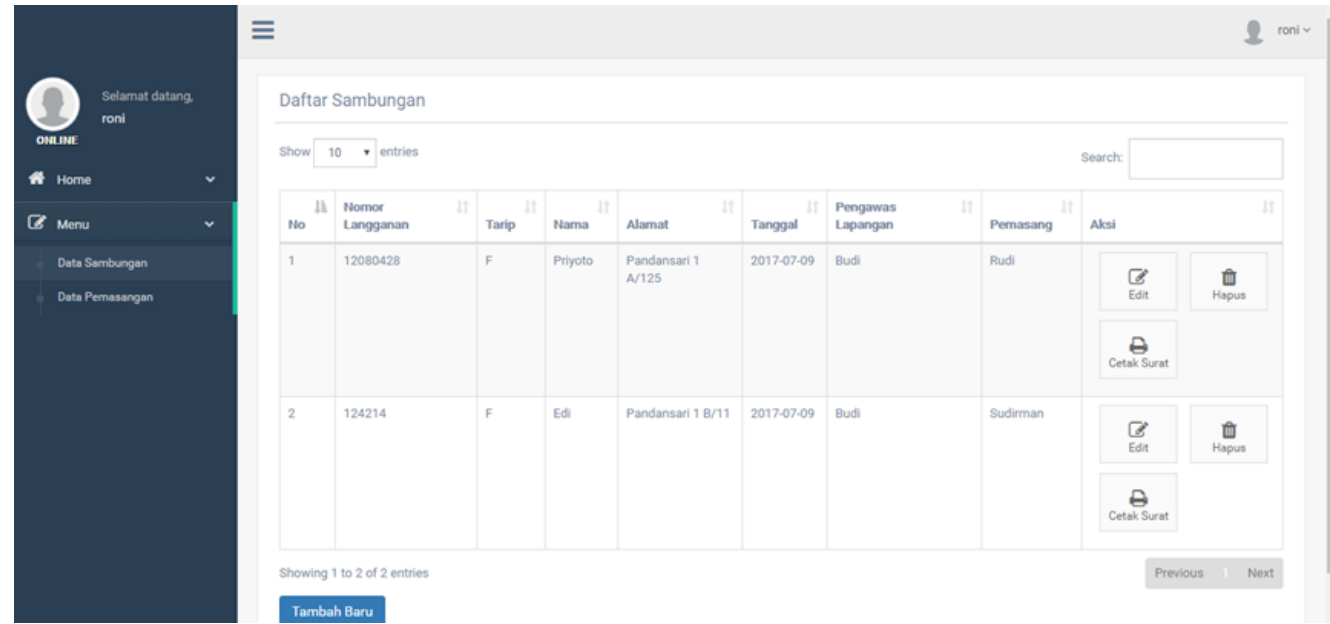

Gambar 10. Tampilan Pengelolaan Data Sambungan

Pada Gambar 10. menu diatas dapat melakukan penambahan data baru dengan mengeklik tombol "Tambah Baru" dan akan menampilkan form yang meminta user untuk melakukan pengisian data sambungan baru. Tampilan form tersebut diasajikan pada Gambar 11.

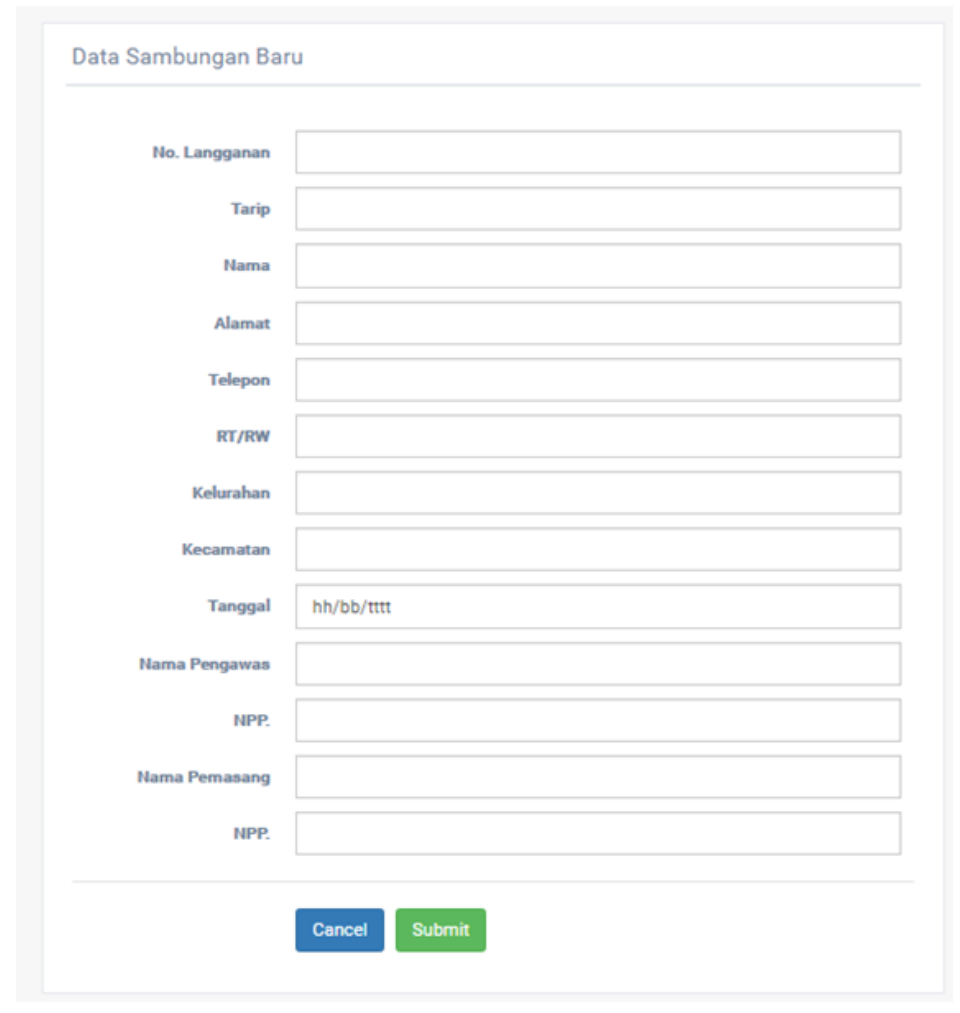

Gambar 11. Form Data Sambungan Baru

Setelah selesai melakukan pengisian data, selanjutnya melakukan proses cetak surat berita acara dengan memilih tombol "Cetak" pada kolom Aksi. File surat berita berekstensi pdf, ekstensi yang paling populer digunakan untuk dokumen. Hasil surat yang diterbitkan ditujukan pada Gambar 12. berikut. 


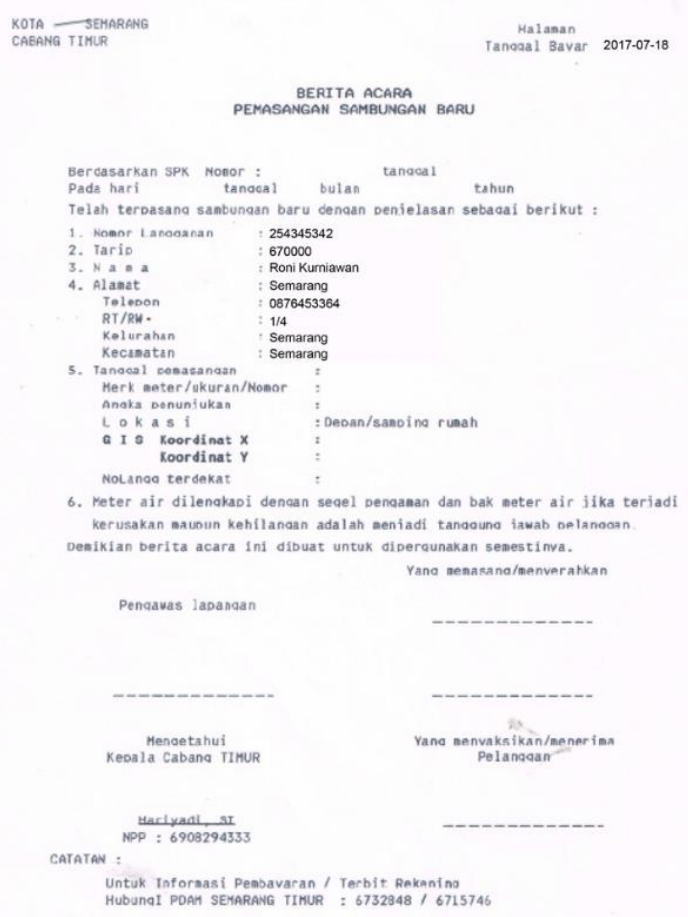

Gambar 12. Surat Berita Acara Pemasangan Sambungan Baru

Menu kedua yaitu menu Data pemasangan. Pada menu ini kita dapat melakukan penambahan data pemasangan baru, edit data dan tentunya melakukan cetak surat. Berikut tampilan data pemasangan meter air ditujukan pada Gambar 13.
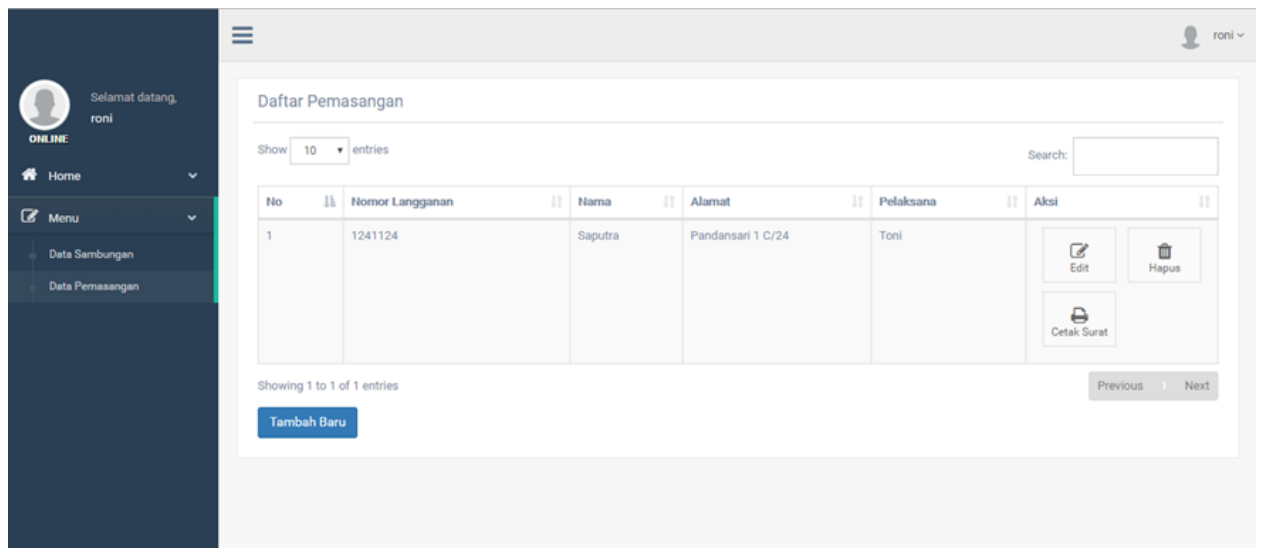

Gambar 13. Tampilan Data Pemasangan

Pada Gambar 13 untuk menambahkan data baru kita dapat menekan tombol "Tambah Baru" lalu sistem akan menampilkan form data pemasangan baru seperti yang ditujukan pada Gambar 14. Pada halaman tersebut user akan mengisikan field nomor langganan, nama, alamat, nama pelaksana dan NPP. Setelah melakukan input data user dapat melakukan cetak dan hasilnya berupa file.pdf yang ditunjukan pada Gambar 15. 

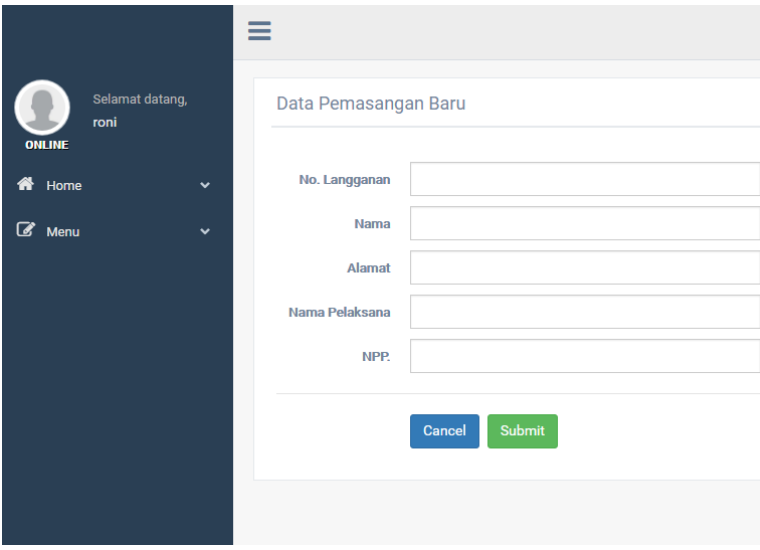

Gambar 14. Form Data Pemasangan Baru

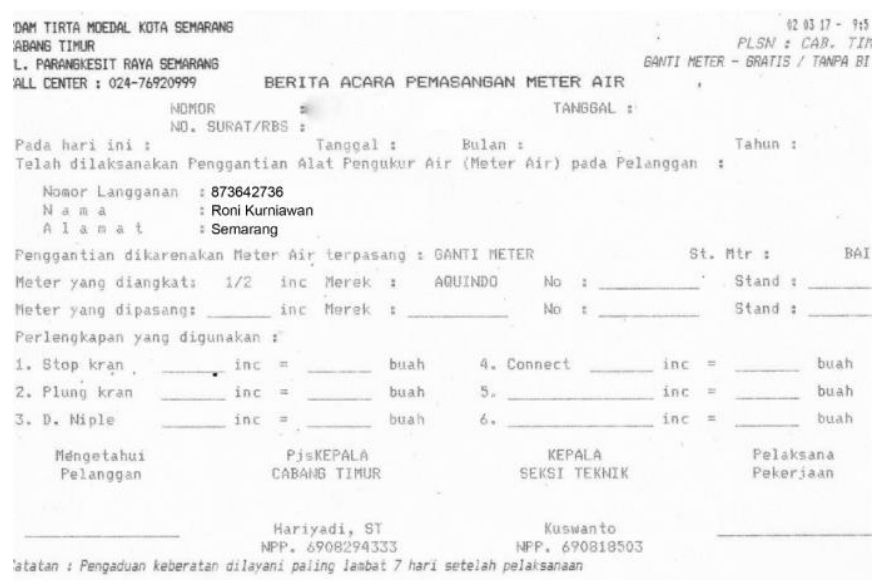

Gambar 15. Hasil Surat Berita Acara Pemasangan Meter Air

Analisis kelayakan sistem dilakukan dengan menggunakan pendekatan kualitatif dengan memberikan daftar pernyataan kepada dua ahli web. Kemudian teknik ukuran yang digunakan yaitu ukuran Skala Likert. Adapun pernyataan yang dinilai ditunjukan pada Tabel 1.

Tabel 1. Pernyataan Analisis Kelayakan Sistem

\begin{tabular}{|c|l|}
\hline No. & \multicolumn{1}{|c|}{ Pernyataan } \\
\hline 1. & Tampilan sistem informasi sudah sesuai dengan baik \\
\hline 2. & Database sistem sesuai dan dapat diterapkan dengan baik \\
\hline 3. & Otentifikasi pada sistem sudah dapat berjalan dengan baik \\
\hline 4. & Navigasi pada sistem dapat dipahami oleh pengguna dengan mudah \\
\hline 5. & Pengelolaan data dapat dipahami oleh pengguna dengan mudah \\
\hline 6. & Tujuan penggunaan sistem informasi tercapai \\
\hline 7. & $\begin{array}{l}\text { Usability pada sistem informasi mudah digunakan dan dipahami oleh } \\
\text { pengguna }\end{array}$ \\
\hline
\end{tabular}

Keterangan bobot diukur dengan pemberian nilai terhadap keterangan Sangat Setuju, Setuju, Netral/Tidak Berpendapat, Tidak Setuju, Sangat Tidak Setuju. Keterangan bobot ditujukan pada Tabel 2. 
Tabel 2. Keterangan Bobot

\begin{tabular}{|l|l|l|l|}
\hline No. & Jawaban & Keterangan & Bobot Nilai \\
\hline 1. & SS & Sangat Setuju & 5 \\
\hline 2. & S & Setuju & 4 \\
\hline 3. & N & $\begin{array}{l}\text { Netral/Tidak } \\
\text { Berpendapat }\end{array}$ & 3 \\
\hline 4. & TS & Tidak Setuju & 2 \\
\hline 5. & STS & Sangat Tidak Setuju & 1 \\
\hline
\end{tabular}

Hasil dari pembobotan akan dimasukan dalam garis kontinum kategori (bentuk rentang). Adapun garis kontinum kategori ditujukan pada Gambar 16.

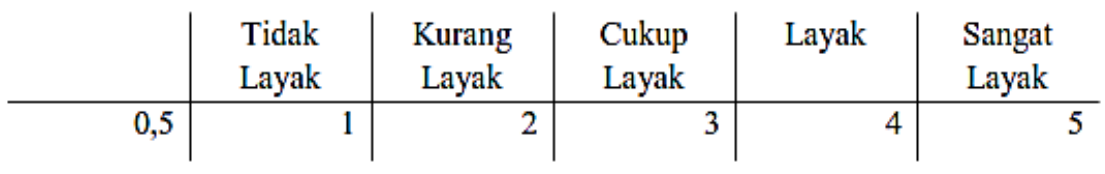

Gambar 16. Garis Kontinum Kategori

Setelah mendapatkan data analisis kelayakan dari dua ahli web, data tersebut akan ditentukan sesuai garis kontinum. Hasil perhitungan lembar evaluasi untuk setiap pernyataan ditujukan pada Tabel 3.

Tabel 3. Hasil Perhitungan Kelayakan Sistem

\begin{tabular}{|c|c|c|c|c|}
\hline No. & Pernyataan & Jawaban & Jumlah & Nilai \\
\hline \multirow[t]{5}{*}{1.} & \multirow{5}{*}{$\begin{array}{l}\text { Tampilan sistem informasi } \\
\text { sudah sesuai dengan baik }\end{array}$} & Sangat Setuju & 2 & 10 \\
\hline & & Setuju & 0 & 0 \\
\hline & & Netral & 0 & 0 \\
\hline & & Tidak Setuju & 0 & 0 \\
\hline & & Tidak Sangat Setuju & 0 & 0 \\
\hline \multicolumn{4}{|c|}{ Jumlah Nilai } & 10 \\
\hline \multicolumn{4}{|c|}{ Angka Kategori } & 5 \\
\hline \multirow[t]{5}{*}{2.} & \multirow{5}{*}{$\begin{array}{l}\text { Database sistem sesuai dan } \\
\text { dapat diterapkan dengan baik }\end{array}$} & Sangat Setuju & 1 & 5 \\
\hline & & Setuju & 1 & 4 \\
\hline & & Netral & 0 & 0 \\
\hline & & Tidak Setuju & 0 & 0 \\
\hline & & Tidak Sangat Setuju & 0 & 0 \\
\hline \multicolumn{4}{|c|}{ Jumlah Nilai } & 9 \\
\hline \multicolumn{4}{|c|}{ Angka Kategori } & 4.5 \\
\hline \multirow[t]{5}{*}{3.} & \multirow{5}{*}{$\begin{array}{l}\text { Otentifikasi pada sistem sudah } \\
\text { dapat berjalan dengan baik }\end{array}$} & Sangat Setuju & 1 & 5 \\
\hline & & Setuju & 1 & 4 \\
\hline & & Netral & 0 & 0 \\
\hline & & Tidak Setuju & 0 & 0 \\
\hline & & Tidak Sangat Setuju & 0 & 0 \\
\hline \multicolumn{4}{|c|}{ Jumlah Nilai } & 9 \\
\hline \multicolumn{4}{|c|}{ Angka Kategori } & 4.5 \\
\hline \multirow[t]{2}{*}{4.} & & Sangat Setuju & 0 & 0 \\
\hline & & Setuju & 1 & 4 \\
\hline
\end{tabular}




\begin{tabular}{|c|c|c|c|c|}
\hline & Navigasi pada sistem dapat & Netral & 1 & 3 \\
\hline & dipahami oleh pengguna & Tidak Setuju & 0 & 0 \\
\hline & dengan mudah & Tidak Sangat Setuju & 0 & 0 \\
\hline & Jum & Nilai & & 7 \\
\hline & Angk: & ategori & & 3.5 \\
\hline 5 . & Pengelolaan data dapat & Sangat Setuju & 0 & 0 \\
\hline & dipahami oleh pengguna & Setuju & 2 & 8 \\
\hline & dengan mudah & Netral & 0 & 0 \\
\hline & & Tidak Setuju & 0 & 0 \\
\hline & & Tidak Sangat Setuju & 0 & 0 \\
\hline & Jum & Nilai & & 8 \\
\hline & Angk & ategori & & 4 \\
\hline 6. & Tujuan penggunaan sistem & Sangat Setuju & 0 & 0 \\
\hline & informasi tercapai & Setuju & 2 & 8 \\
\hline & & Netral & 0 & 0 \\
\hline & & Tidak Setuju & 0 & 0 \\
\hline & & Tidak Sangat Setuju & 0 & 0 \\
\hline & Jum & Nilai & & 8 \\
\hline & Angk & ategori & & 4 \\
\hline 7. & Usability pada sistem & Sangat Setuju & 1 & 5 \\
\hline & informasi mudah digunakan & Setuju & 1 & 4 \\
\hline & dan dipahami oleh pengguna & Netral & 0 & 0 \\
\hline & & Tidak Setuju & 0 & 0 \\
\hline & & Tidak Sangat Setuju & 0 & 0 \\
\hline & Jum & Nilai & & 9 \\
\hline & Angk: & ategori & & 4.5 \\
\hline
\end{tabular}

Setelah mendapatkan penilaian, maka setiap angka kategori akan ditentukan masuk ke dalam kategori apa dan hasilnya akan ditentukan berdasarkan rata-ratanya. Hasil analisis kelayakan ditunjukan pada Tabel 4.

\begin{tabular}{|c|l|c|c|}
\hline No. & \multicolumn{1}{|c|}{ Pernyataan } & Angka Kategori & Kategori \\
\hline 1. & $\begin{array}{l}\text { Tampilan sistem informasi } \\
\text { sudah sesuai dengan baik }\end{array}$ & 5 & Sangat Layak \\
\hline 2. & $\begin{array}{l}\text { Database sistem sesuai dan } \\
\text { dapat diterapkan dengan baik }\end{array}$ & 4.5 & Sangat Layak \\
\hline 3. & $\begin{array}{l}\text { Otentifikasi pada sistem sudah } \\
\text { dapat berjalan dengan baik }\end{array}$ & 4.5 & Langat Layak \\
\hline 4. & $\begin{array}{l}\text { Navigasi pada sistem dapat } \\
\text { dipahami oleh pengguna } \\
\text { dengan mudah dapat }\end{array}$ & 3.5 & Layak \\
\hline 5. & $\begin{array}{l}\text { Pengelolaan data dan pengguna } \\
\text { dipahami oleh } \\
\text { dengan mudah }\end{array}$ & & \\
\hline
\end{tabular}




\begin{tabular}{|c|l|c|c|}
\hline 6. & $\begin{array}{l}\text { Tujuan penggunaan sistem } \\
\text { informasi tercapai }\end{array}$ & 4 & Layak \\
\hline 7. & $\begin{array}{l}\text { Usability pada sistem informasi } \\
\text { mudah digunakan dan } \\
\text { dipahami oleh pengguna }\end{array}$ & 4.5 & Sangat Layak \\
\hline \multicolumn{2}{|c|}{ Jumlah } & 30 & Sangat Layak \\
\hline
\end{tabular}

Hasil analisis kelayakan yang diperoleh ialah 4.28 dengan kategori Sangat Layak. Sehingga sistem informasi penerbitan surat di PDAM Tirta Moedal Kota Semarang Cabang Timur dapat digunakan untuk menggantikan penggunaan Ms Excel dalam penerbitan surat. Adanya sistem informasi, data yang diisikan dapat terrekam dengan terstruktur. Selain itu, memudahkan bagi pegawai dalam melakukan aktivitas kerjanya.

\section{KESIMPULAN}

Berdasarkan hasil dalam pembahasan yang telah dilakukan, maka dapat disimpulkan:

1. Perancangan sistem informasi penerbitan surat berita acara pemasangan dapat diimplementasikan dengan baik menggunakan bahasa pemograman PHP dan menggunakan database MySql. Dalam pembuatan perancangan sistem informasi ini melalui tahapan SDLC dari tahap Planning, Analysis, Design, Implementation, dan Maintainance.

2. Hasil analisis kelayakan yang dilakukan dengan skala likert dan garis kontinum diperoleh nilai kelayakan sistem sebesar 4.28 dengan kategori Sangat Layak untuk diterapkan.

\section{SARAN}

Berdasakan hasil penelitian, adapun saran yang ingin disampaikan antara lain:

1. Sistem sebaiknya diujikan terlebih dahulu ke beberapa responden terkait penerbitan surat dan pimpinan yang ada di PDAM Tirta Moedal Kota Semarang Cabang Timur. Hal tersebut agar sistem memeroleh banyak saran dan masukan serta penyesuaian kebijakan dalam penerbitan surat

2. Fitur penerbitan surat tidak hanya terkait pemsangan namun juga bisa surat berita acara lainnya agar penerbitan surat lebih terkoordinir dalam satu sistem.

\section{UCAPAN TERIMA KASIH}

Penulis mengucapkan terima kasih kepada PDAM Tirta Moedal Kota Semarang Cabang Timur dan Jurusan Ilmu Komputer FMIPA, Universitas Negeri Semarang atas dukungan dalam terlaksanakannya penelitian ini.

\section{DAFTAR PUSTAKA}

[1] Usman, U. and Gladinda, G., 2017, Perancangan Sistem Informasi Pengolahan Data Surat Persetujuan Berlayar di Kantor Unit Penyelenggara Pelabuhan Kelas III Kuala Gaung, SISTEMASI, 6(2), pp.9-17.

[2] Fathansyah. 1999, Basis Data, Informatika, Bandung

[3] Muzakir, A., \& Wulandari, R. A. 2016, Model Data Mining sebagai Prediksi Penyakit Hipertensi Kehamilan dengan Teknik Decision Tree, Scientific Journal of Informatics, $3(1), 19-26$. 
[4] Gunawan, G., Lawi, A. and Adnan, A., 2016, Analisis Arsitektur Aplikasi Web Menggunakan Model View Controller (MVC) pada Framework Java Server Faces, Scientific Journal of Informatics, 3(1), pp.55-67.

[5] Kadir, A. 2002, Pengenalan Sistem Informasi, Andi, Yogyakarta.

[6] Sugiharti, E., \& Triliani, S. E. (2014). Perancangan Aplikasi Surat Masuk dan Keluar pada PT. Angkasa Pura 1 Semarang. Scientific Journal of Informatics, 1(1), 39-52.

[7] Muslim, M.A., 2012, Pengembangan Sistem Informasi Jurusan Berbasis Web Untuk Meningkatkan Pelayanan dan Akses Informasi, Jurnal MIPA, 35(1).

[8] Kristanto, A. 2008, Perancangan Sistem Informasi dan Aplikasinya, Gava Media, Yogyakarta.

[9] Nugroho, Z. A., \& Arifudin, R. 2014, Sistem Informasi Tracer Study Alumni Universitas Negeri Semarang Dengan Aplikasi Digital Maps, Scientific Journal of Informatics, 1(2), 153-160.

[10] Putra, A. T. 2014, Pengembangan E-Lecture menggunakan Web Service Sikadu untuk Mendukung Perkuliahan di Universitas Negeri Semarang, Scientific Journal of Informatics, 1(2), 168-176. 